\title{
Henry Kellett (1806-1875)
}

Henry Kellett was born in West Ireland and joined the Navy too late to share in the Napoleonic War, but he found employment in the coastal surveys, which were an important part of the Navy's duties in the peaceful years of the nineteenth century. He served in the China War and was promoted post-captain.

When the search for the crews of John Franklin's missing expedition began, Kellett was in command of the frigate Herald, charting the Pacific coast of Lower California; his new orders directed him to spend the summer carrying supplies to the lookout ship Plover in Kotzebue Sound, Alaska, and to make excursions into the western Canadian Arctic. Both Kellett and the commander of the Plover were in the sound when the Investigator, under Robert McClure, arrived. The Investigator had been placed under the orders of Captain Collinson of the Enterprise, which was still en route to Kotzebue Sound from Honolulu, but McClure - ambitious and none too scrupulous - had availed himself of a defect in his orders to slip away and make an independent search. McClure justified this course by pretending that Collinson had slipped through Bering Strait unobserved and might still be ahead of him. Neither Kellett nor the Plover's captain would countenance this pretence; Kellett, however, had scruples about meddling with the urgent search for Franklin's expedition, and although he was the senior officer, he permitted McClure to plunge into the Arctic, where he vanished for almost three years.

Shortly afterwards, Kellett was recalled to England and given command of the Resolute, a part of the search fleet under Sir Edward Belcher. After passing through Lancaster Sound, Belcher left the North Star as depot ship at Beechey Island, while he took the Assistance and the Pioneer up Wellington Channel. He directed the Resolute and the tender Intrepid to proceed west to Melville Island and, if need arose, to afford help to Collinson or McClure. Finding Parry's Winter Harbour ice blocked, Kellett secured winter protection between the Melville Island coast and little Dealy Island. From there, an officer tramped to Winter Harbour and found in a cache McClure's Journal of Proceedings, from which it was learned that the Investigator had discovered the Northwest Passage, and that McClure's ship had

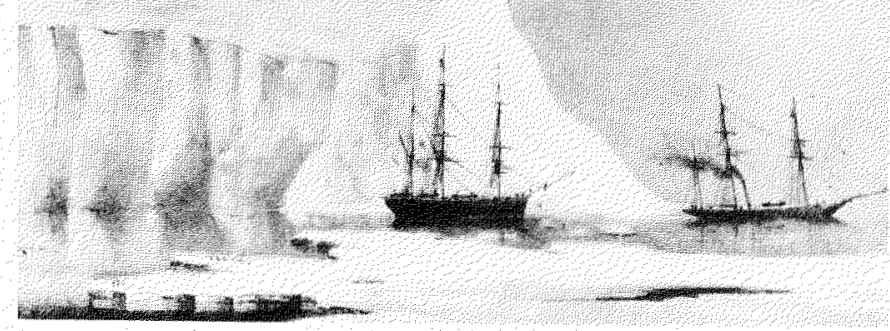

Resolute and Intrepid passing an iceberg in Baffin Bay, July 1852. Both illustrations are from McDougall's Voyage of H.M.S. "Resolute." lain and might still be lying at Mercy Bay on the north shore of Banks Island.

Winter, however, was too far advanced by that time for Kellett to attempt a crossing of Viscount Melville Sound. But there was reason to fear that McClure's supplies were running low and that his men might be driven to make a trek for the continental mainland. Lieutenant Bedford Pim finally eased his captain's anxiety by volunteering to cross the sound, but not until the cold of early March. Travelling by dog sledge, Pim narrowly arrived in time to avert any such hopeless land journey by McClure.

McClure sent his invalids, his interpreter Johann Miertsching, and Lieutenant Cresswell back to join the Resolute; he still hoped to extricate his ship from the ice of Mercy Bay. But Kellett, shocked at the haggard aspect of the half-starved invalids, ordered McClure to abandon his ship and to bring his entire crew to join the Resolute. The Resolute and Intrepid then sailed east, but were frozen in at Barrow Strait, and the hapless crew that had manned the Investigator had to spend a fourth winter in the ice. Sir Edward Belcher, unjustifiably in Kellett's opinion, ordered four of the ships under his command abandoned; crews were ordered to tramp to Beechey Island for transport home on summer supply ships. By producing their superiors' orders, Kellett and McClure were promptly acquitted for the loss of their ships. After a rough passage through court-martial, Belcher, too, was granted a grudging acquittal.

It was resolved to make a handsome grant to the discoverers of the Northwest Passage, and a House of Commons committee sat to apportion shares to the crews of Collinson, McClure, and Kellett. Collinson withdrew all claim and magnanimously refrained from complaining of McClure's desertion. Kellett's position was strong, as but for him the Investigator and the record of its exploit might have disappeared as Franklin had done. But McClure smoothly explained that he had not required the Resolute's aid. Without it, he might have got his men to the whalers in Baffin Bay with only four casualties. This was contrary to the opinion of the surgeon, Armstrong, and in flat contradiction to the German Miertsching's assertion that "had not our gracious and merciful Lord and Saviour intervened, and by bringing these ships [the Resolute and the Intrepid] at the right time, cancelled our intended long journey at the last moment, we must all have perished miserably on the frozen sea." The gross ingratitude of this impudent assertion seems not to have deceived the committee; nonetheless, it awarded the entire grant of $£ 10,000$ to the officers and men of the Investigator, dismissing Kellett with a few words of commendation, more galling than any insult. This decision may be ascribed to the wish to exalt as much as possible British prestige, which had suffered much from the mismanagement of the Crimean War.

Kellett later commanded the British squadron on the China station, where he won the praise of that tempestuous critic of naval administration, the future Admiral Lord Fisher.

Although he hardly rates as an explorer, Sir Henry Kellett rendered a most valuable service to polar history by rescuing the Investigator and so preserving the record of her sensational and often perilous voyage. 


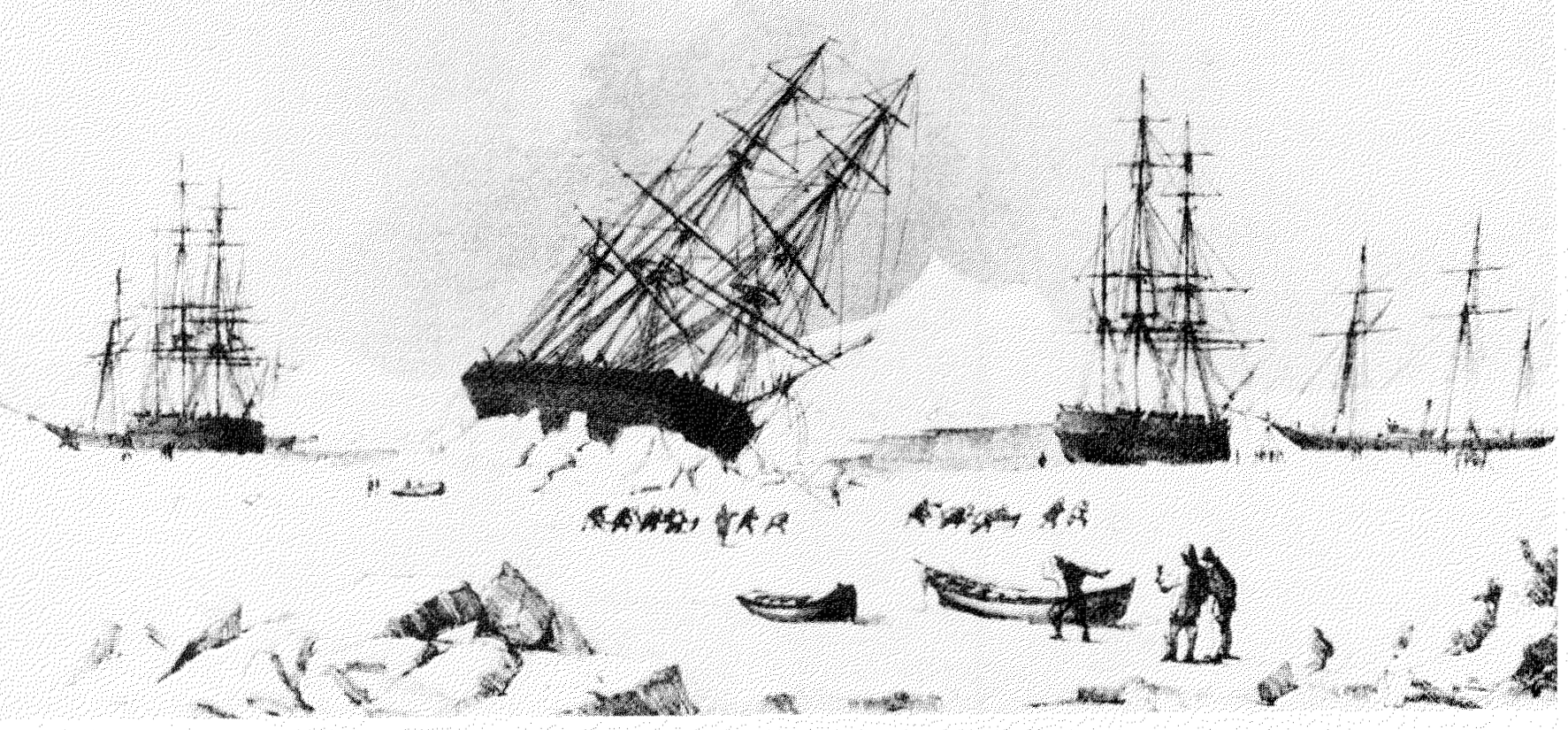

The five ships under Belcher's command, Baffin Bay, June 1852. Intrepid is' on far left, Resolute in centre.

\section{FURTHER READINGS}

MCDOUGALL, G.F.M. 1852. The Eventful Voyage of H.M. Discovery Ship

"Resolute" to the Arctic Regions, in Search of Sir John Franklin and the Missing Crews of H.M. Discovery Ships "Erebus" and "Terror," 1852-54. London: Longman, Brown, Green, Longmans, \& Roberts.

NEATBY, L.H. 1970. The Search for Franklin. Edmonton: Hurtig Publishers. WRIGHT, NOEL. 1959. Quest for Franklin. Toronto: Heinemann.

\section{L.H. Neatby}

1212 Osler Street

Saskatoon, Saskatchewan, Canada S7N 0T9 